\title{
Evaluating A Semi-Nested PCR to Support Histopathology Reports of Fungal Rhinosinusitis in Formalin-Fixed Paraffin-Embedded Tissue Samples.
}

\author{
Mohammad Javad Ashraf \\ Shiraz University of Medical Sciences \\ Mohammad Kord \\ Shiraz University of Medical Sciences \\ Hamid Morovati \\ Shiraz University of Medical Sciences
}

\section{Saham Ansari}

Shahid Beheshti University of Medical Sciences

\section{Golsa Shekarkhar}

Shiraz University of Medical Sciences

Hamid Badali

University of Texas Health Science Center at San Antonio

\section{Kayvan Pakshir}

Shiraz University of Medical Sciences

\section{Foroogh Shamsizadeh}

Shiraz University of Medical Sciences

\section{Bijan Khademi}

Shiraz University of Medical Sciences

\section{Mahmood Shishegar}

Shiraz University of Medical Sciences

\section{Kazem Ahmadikia}

Tehran University of Medical Sciences

Kamiar Zomorodian ( $\nabla$ kzomorodian@gmail.com )

Shiraz University of Medical Sciences

\section{Research Article}

Keywords: Fungal rhinosinusitis, Formalin-fixed paraffin-embedded tissue, Histopathology, semi-nested PCR, Sequencing

Posted Date: June 16th, 2021

DOI: https://doi.org/10.21203/rs.3.rs-558660/v1 
License: (c) (i) This work is licensed under a Creative Commons Attribution 4.0 International License. Read Full License

Version of Record: A version of this preprint was published at Journal of Clinical Laboratory Analysis on January 8th, 2022. See the published version at https://doi.org/10.1002/jcla.24209. 


\section{Abstract \\ Background}

Fungal rhinosinusitis (FRS) encompasses a various spectrum of disease, which vary in clinical presentation, histologic features, and biological significance. FRS is commonly classified in two categories, i.e., invasive and non-invasive infection. Histopathology is the "gold standard" diagnostic method, but it is not able to determine the genus and species. Almost more than $50 \%$ of the histopathologically proven cases, the culture elicited no reliable results. This study was an attempt to evaluate the diagnostic efficiency of semi-nested polymerase chain reaction (PCR) to confirmation of pathology reports obtained from formalin-fixed paraffinembedded (FFPE) functional endoscopic sinus surgery (FESS) in FRS patients.

\section{Methods}

One hundred ten specimens were subjected to DNA extraction and histopathology examination. The amplification of $\beta$-globin gene by conventional PCR was used for confirming the quality of extracted DNA. The semi-nested PCR was performed using ITS 1 and ITS4 primers during two steps. In order to identification of causative agents, sequencing of the internal transcribed spacer region (ITS1-5.8S-ITS2) was performed on PCR products.

\section{Results}

Sixty-four out of 110 samples were positive by histopathology evidence, of which 56 samples (87.5\%) were positive by PCR and 8 (12.5\%) samples were negative. Out of 46 negative samples by histopathological methods, 41 samples (89.1\%) were negative in PCR while 5 (10.9\%) were positive. Sensitivity, specificity, positive predictive value, and negative predictive value of the semi-nested PCR method were reported $87.5 \%$, $89.2 \%, 92.7 \%$, and $85.2 \%$, respectively. Aspergillus flavus, Rhizopus oryzae, Lichtheimia corymbifera and Candida albicans have identified as common fungal species.

\section{Conclusion}

Based on staining and direct examination that are time-consuming, applying molecular methods might be an appropriate choice for rapid diagnosis and support the consequences of histopathology examinations. We suggest that fresh biopsy specimens elicit more reliable results in comparison with FFPE samples. It is recommended that semi-nested PCR assays be performed in a single tube, which showed less prone to contamination when compared with assays that were carried out in two stages and in separate tubes.

\section{Trial registration:}

Not applicable. 


\section{Background}

The inflammation of paranasal sinus mucosa is called sinusitis, or rhinosinusitis [1], which commonly affecting approximately 4.5 to $12 \%$ of the North America and European populations and $20 \%$ globally [2]. Direct costs of chronic rhinosinusitis estimated between 12 to 13 billion dollars per year in the United States $[3,4]$. Depending on risk factors, colonization of fungal spores in sinonasal cavities triggers immunopathological consequences, fungal sinusitis, or more accurately fungal rhinosinusitis (FRS) [5]. FRS is being reported increasing worldwide frequency [5]. Elevation in the incidence rate of FRS is a consequence of global escalation in the immunocompromised population [6]. However, significant increasing of FRS reported in immunocompetent hosts without predisposing factors, the situation becomes more complicated [7].

FRS includes a wide range of clinical spectrum encompasses the mild form of superficial colonization and allergic manifestations to life-threatening invasive disease [5]. But histopathologically, FRS is divided into two categories, i.e., invasive and noninvasive infection, depending on tissue invasion of the mucosal layer. The invasive diseases include acute invasive (fulminant) FRS, granulomatous invasive FRS, and chronic invasive FRS, while, the noninvasive diseases include localized colonization, fungal ball, and fungus-related eosinophilic FRS that includes allergic fungal rhinosinusitis (AFRS) $[5,8,9]$.

Diagnosis is always a big challenging in the management of FRS. In addition to clinical signs and symptoms and radiographic manifestations, which are non-specific, more reliable methods are available including direct microscopic examination by potassium hydroxide $(\mathrm{KOH})$, histopathology by Gomori methenamine silver (GMS) and hematoxylin and eosin (H\&E), culture methods by Sabouraud dextrose agar (SDA), Sabouraudchloramphenicol (SC), and Sabouraud-chloramphenicol- Cycloheximide (SCC), antigen/antibody testing (Galactomannan and Alternaria antigen tests), and molecular methods [10, 11]. Moreover, the advanced molecular methods, single PCR, Nested PCR, semi-nested PCR, Quantitative Real-time PCR (qPCR), and hybridization with species-specific probes, are stablished [12-14]. Semi-nested PCR is a modified method planned to restrict non-specific binding in products due to the amplification of unexpected primer binding sites $[12,15]$. The efficacy of molecular and mycological tests is indisputable. The culture of fungal agents of FRS may yield false positive or negative results respectively due to environmental contamination and loss of viability due to improper storage and transferring conditions [16]. Microscopic examination and histopathological techniques remain the gold standard for the detection of fungal elements in FFPE samples [17]. Moreover, histopathology plays a key role in the categorizing of this infection [11]. As the number of fungal elements in the specimens may be low, or not well stained, and the patient smear may not be examined by a trained professional, the test results may not have a proper sensitivity and specificity.

There are several limitations in collecting samples from FRS cases via endoscopy-guided biopsy, of which small amounts of obtained specimen that usually used only for histopathological diagnosis. Therefore, using a reliable molecular method for direct detection of FRS in FFPE samples might improve the diagnosis. Here, we evaluated the diagnostic accuracy and power of semi-nested PCR in comparison with the results of histopathology assay of FFPE in patients with FRS. 


\section{Materials And Methods Samples \& Patients}

In the current prospective cross-sectional study, the FESS samples were collected from 110 patients (64 positive FRS and 46 non-FRS). The status of patients was proved by clinical sign and symptoms and computed tomography (CT) scan. Demographic data of the patients, including age, sex, type of operation, site of infection, background diseases, and final pathology report, were documented (Table 1). The paraffin blocks were prepared for cutting process by microtome. During this process, FESS samples were divided to 10 slices with $5 \mu \mathrm{m}$ thickness. The samples were prepared and put into microtubes to further histopathological and molecular investigations. 
Table 1

Demographic data of the patients and the results of molecular assays

\begin{tabular}{|c|c|c|c|c|c|c|c|}
\hline $\begin{array}{l}\text { Patient } \\
\text { No }\end{array}$ & Sex & Age & Risk Factors & $\begin{array}{l}\text { Pathology } \\
\text { Report }\end{array}$ & Outcome & $\begin{array}{l}\text { PCR } \\
\boldsymbol{\beta} \\
\text { globin/ITS }\end{array}$ & Sequence \\
\hline 1 & $\mathrm{~F}$ & 41 & ND & Chronic FRS & Survived & $+/+$ & A. flavus \\
\hline 2 & $\mathrm{~F}$ & 50 & ND & Chronic FRS & Survived & $+/+$ & C. albicans \\
\hline 3 & $\mathrm{~F}$ & 40 & ND & Chronic FRS & Survived & $+/+$ & A. flavus \\
\hline 4 & $\mathrm{~F}$ & 52 & Leukemia & Mucormycosis & Died & $+/+$ & - \\
\hline 5 & $\mathrm{~F}$ & 42 & Diabetic & Mucormycosis & Survived & $+/+$ & R. oryzae \\
\hline 6 & $\mathrm{~F}$ & 50 & Leukemia & Acute FRS & Died & $+/+$ & A. flavus \\
\hline 7 & $M$ & 55 & ND & Mucormycosis & Died & $+/-$ & - \\
\hline 8 & $M$ & 2 & Leukemia & Chronic FRS & Survived & $+/+$ & A. flavus \\
\hline 9 & $\mathrm{~F}$ & 63 & Leukemia & Mucormycosis & Survived & $+/+$ & - \\
\hline 10 & $M$ & 21 & Allergy & Chronic FRS & Survived & $+/+$ & $\begin{array}{l}\text { Cr. } \\
\text { ozbekistanensis }\end{array}$ \\
\hline 11 & $M$ & 51 & ND & Chronic FRS & Survived & $+/+$ & A. flavus \\
\hline 12 & $M$ & 26 & $\begin{array}{l}\text { Leukemia - } \\
\text { Allergy }\end{array}$ & Mucormycosis & Survived & $+/-$ & - \\
\hline 13 & M & 58 & ND & Chronic FRS & Survived & $+/+$ & A. flavus \\
\hline 14 & $\mathrm{~F}$ & 47 & ND & Chronic FRS & Survived & $+/+$ & C. albicans \\
\hline 15 & $M$ & 32 & Allergy & Chronic FRS & Survived & $+/+$ & A. fumigatus \\
\hline 16 & $M$ & 26 & ND & Chronic FRS & Survived & $+/+$ & - \\
\hline 17 & $\mathrm{~F}$ & 42 & ND & Mucormycosis & Died & $+/+$ & R. oryzae \\
\hline 18 & M & 43 & ND & Chronic FRS & Survived & $+/+$ & - \\
\hline 19 & $M$ & 20 & Diabetic & Mucormycosis & Survived & $+/+$ & - \\
\hline 20 & $\mathrm{~F}$ & 49 & ND & Mucormycosis & Survived & $+/+$ & R. microsporus \\
\hline 21 & $\mathrm{~F}$ & 42 & Diabetic & Acute FRS & Survived & $+/+$ & A. oryzae \\
\hline 22 & $M$ & 25 & Leukemia & Mucormycosis & Survived & $+/+$ & - \\
\hline 23 & $M$ & 36 & Diabetic & Mucormycosis & Died & $+/+$ & - \\
\hline 24 & $\mathrm{~F}$ & 44 & ND & Mucormycosis & Died & $+/+$ & L. corymbifera \\
\hline 25 & $\mathrm{~F}$ & 53 & ND & Mucormycosis & Survived & $+/+$ & - \\
\hline
\end{tabular}




\begin{tabular}{|c|c|c|c|c|c|c|c|}
\hline $\begin{array}{l}\text { Patient } \\
\text { No }\end{array}$ & Sex & Age & Risk Factors & $\begin{array}{l}\text { Pathology } \\
\text { Report }\end{array}$ & Outcome & $\begin{array}{l}\text { PCR } \\
\boldsymbol{\beta} \\
\text { globin/ITS }\end{array}$ & Sequence \\
\hline 26 & $\mathrm{~F}$ & 35 & Leukemia & Mucormycosis & Died & $+/+$ & - \\
\hline 27 & $\mathrm{~F}$ & 32 & ND & Chronic FRS & Survived & $+/+$ & A. alternate \\
\hline 28 & $M$ & 26 & ND & Chronic FRS & Survived & $+/+$ & A. parasiticus \\
\hline 29 & $\mathrm{~F}$ & 70 & Leukemia & Chronic FRS & Survived & $+/+$ & A. flavus \\
\hline 30 & $M$ & 53 & Leukemia & Mucormycosis & Survived & $+/+$ & - \\
\hline 31 & $\mathrm{~F}$ & 25 & Leukemia & Mucormycosis & Died & $+/+$ & - \\
\hline 32 & $M$ & 65 & ND & Mucormycosis & Survived & $+/-$ & - \\
\hline 33 & $F$ & 20 & Leukemia & Mucormycosis & Died & $+/+$ & - \\
\hline 34 & $F$ & 52 & Addiction & Chronic FRS & Died & $+/+$ & A. flavus \\
\hline 35 & $M$ & 55 & ND & Mucormycosis & Survived & $+/+$ & - \\
\hline 36 & $M$ & 55 & Diabetic & Mucormycosis & Survived & $+/+$ & R. oryzae \\
\hline 37 & $\mathrm{~F}$ & 59 & Leukemia & Mucormycosis & Died & $+/+$ & R. oryzae \\
\hline 38 & $\mathrm{~F}$ & 59 & Leukemia & Mucormycosis & Died & $+/+$ & R. oryzae- \\
\hline 39 & $M$ & 34 & Polyp & $\begin{array}{l}\text { Acute and } \\
\text { chronic FRS }\end{array}$ & Survived & $+/+$ & A. flavus \\
\hline 40 & $\mathrm{~F}$ & 37 & Leukemia & Mucormycosis & Died & $+/+$ & - \\
\hline 41 & $\mathrm{~F}$ & 64 & $\begin{array}{l}\text { Autoimmune } \\
\text { disease }\end{array}$ & Mucormycosis & Survived & $+/-$ & R. oryzae \\
\hline 42 & $\mathrm{~F}$ & 61 & ND & Chronic FRS & Survived & $+/+$ & - \\
\hline 43 & $\mathrm{~F}$ & 6 & Leukemia & Mucormycosis & Died & $+/+$ & - \\
\hline 44 & $M$ & 52 & Transplantation & Mucormycosis & Died & $+/+$ & R. oryzae \\
\hline 45 & $M$ & 50 & $\begin{array}{l}\text { Diabetic- } \\
\text { Transplantation }\end{array}$ & Mucormycosis & Died & $+/+$ & R. oryzae \\
\hline 46 & $M$ & 51 & Transplantation & Mucormycosis & Died & $+/-$ & - \\
\hline 47 & $\mathrm{~F}$ & 55 & $\begin{array}{l}\text { Diabetic- } \\
\text { Transplantation }\end{array}$ & Mucormycosis & Died & $+/+$ & $\begin{array}{l}\text { Saksenaea } \\
\text { vasiformis }\end{array}$ \\
\hline 48 & $M$ & 20 & ND & Mucormycosis & Died & $+/+$ & - \\
\hline 49 & $\mathrm{~F}$ & 53 & ND & Mucormycosis & Survived & $+/+$ & L. corymbifera \\
\hline 50 & $\mathrm{~F}$ & 51 & $\begin{array}{l}\text { Diabetic- } \\
\text { Leukemia }\end{array}$ & Mucormycosis & Survived & $+/+$ & - \\
\hline
\end{tabular}




\begin{tabular}{|llllllll|}
\hline $\begin{array}{l}\text { Patient } \\
\text { No }\end{array}$ & Sex & Age & Risk Factors & $\begin{array}{l}\text { Pathology } \\
\text { Report }\end{array}$ & Outcome & PCR & Sequence \\
51 & F & 52 & ND & Chronic FRS & Survived & $+/+$ & A. flavus \\
\hline 52 & F & 34 & $\begin{array}{l}\text { Diabetic- } \\
\text { Leukemia }\end{array}$ & Mucormycosis & Survived & $+/+$ & - \\
\hline 53 & M & 56 & Diabetic & Mucormycosis & Died & $+/+$ & - \\
\hline 54 & M & 30 & Leukemia & Mucormycosis & Survived & $+/+$ & R. oryzae \\
\hline 55 & F & 62 & Diabetic & Mucormycosis & Died & $+/-$ & - \\
\hline 56 & F & 49 & Diabetic & Chronic FRS & Survived & $+/+$ & C. albicans \\
\hline 57 & M & 6 & Leukemia & Mucormycosis & Survived & $+/+$ & - \\
\hline 58 & F & 46 & Diabetic & Chronic FRS & Survived & $+/+$ & A. flavus \\
\hline 59 & F & 22 & Leukemia & Mucormycosis & Died & $+/+$ & - \\
\hline 60 & M & 51 & Leukemia & Mucormycosis & Survived & $+/+$ & R. oryzae \\
\hline 61 & M & 33 & Diabetic & Chronic FRS & Survived & $+/+$ & A. flavus \\
\hline 62 & F & 47 & Leukemia & Mucormycosis & Died & $+/-$ & - \\
\hline 63 & F & 4 & Leukemia & Mucormycosis & Survived & $+/+$ & L. corymbifera \\
\hline 64 & M & 9 & Diabetic & Mucormycosis & Died & $+/-$ & - \\
\hline De & & & & & - \\
\hline
\end{tabular}

\section{Deparaffinization Process}

To reduce the contamination of samples during this process, it recommended the sterilization of microtome and other instruments using benzene and $2 \mathrm{M} \mathrm{HCl}$ rinsed with sterile water (www. leicabiosystems.com). The $1000 \mu \mathrm{l}$ of xylene was added to microtube containing $5 \mu \mathrm{m}$ of sample, which was then incubated in $56^{\circ} \mathrm{C}$ on a heating block for $15 \mathrm{~min}$ at room temperature and section subsequently centrifuged at $10,000 \times g$ for 2 min. The supernatant was removed and $1,000 \mu \mathrm{l}$ of absolute ethanol was added and followed by centrifugation at $10,000 \times g$ for $3 \mathrm{~min}$. The previous stage was repeated for 3 times then the tubes were incubated at $37^{\circ} \mathrm{C}$ on a heating block until the total evaporation of the ethanol [18].

\section{Histopathological assay}

The FFPE FESS samples were stained by hematoxylin and eosin (H\&E), Periodic Acid Schiff (PAS) stains. The staining processes were performed according to the protocols for FFPE sample staining [19].

\section{DNA extraction}

DNA was extracted as previously described. Briley, $100 \mu$ lysis buffer, $180 \mu$ l of ATL buffer, and $20 \mu \mathrm{l}$ of proteinase $\mathrm{K}$ were added to the tube samples. After overnight incubation at $56^{\circ} \mathrm{C}$, the tubes were washed via normal saline. To complete the lysis process, tubes were heated in boiling water for 5 minutes. The tubes 
were incubated in boiling water and liquid nitrogen for $1 \mathrm{~min}$ and $2 \mathrm{~min}$, respectively. This step was repeated several times. Finally, they reached room temperature. DNA extraction was completed by QIAamp DNA extraction from tissue mini kit (Qiagen, Hilden, Germany), as previously described [20]. This process is based on the binding of the DNA to silica columns.

\section{PCR Assay}

To evaluate the quality of the extracted DNA, human $\beta$-globin gene fragments amplificated by the PCR method [21, 22] and KM29/PCO4 primers. PCR process was performed in a total volume of $25 \mu$ l. So that, the master mix containing $1 \mathrm{mM} \mathrm{MgCl}_{2}, 200 \mu \mathrm{M}$ deoxyribonucleotide triphosphates solution (dNTP)s, $1 \mathrm{X}$ reaction buffer10x, $1 U$ Taq DNA polymerase (total of Cinna Gene, Iran), and $1 \mu \mathrm{l}(10$ picomols) of forward and reverse primers (Table 2). PCR conditions were as follows; denaturation phase 1 cycle at $94^{\circ} \mathrm{C}$ for $10 \mathrm{~min}$ followed by 35 cycles of $94^{\circ} \mathrm{C}$ for $45 \mathrm{~s}, 58^{\circ} \mathrm{C}$ for $45 \mathrm{~s}$ and $72^{\circ} \mathrm{C}$ for $5 \mathrm{~min}$, and a final extension at $72^{\circ} \mathrm{C}$ for $7 \mathrm{~min}$. Amplicon quality and concentrations were estimated on the agarose gel and analyzed by the Gel Doc XR system (Biorad, USA). The smart Ladder (Eurogentec, Seraing-Belgium) was used as the size and concentration marker.

Table 2

Primers used for internal control and detection Fungal DNA by semi-nested PCR

\begin{tabular}{|lll|}
\hline Primers & $\mathbf{5} \rightarrow \mathbf{3}$ sequence & References \\
\hline$\beta$ globin (F:KM29) & GGT TGG CCA ATC TAC TCC CAG G & \\
\hline$\beta$ globin (R:PCO4) & CAA CTT CAT CCA CGT TCA CC \\
\hline ITS1 (F) & TCC GTA GGT GAA CCT GCG G \\
\hline ITS2 (R) & GCT GCG TTC TTC ATC GAT GC \\
\hline ITS4 (R) & TCC TCC GCT TAT TGA TAT GC \\
\hline
\end{tabular}

\section{Semi-nested PCR Assay}

Universal fungal ITS region (ITS1-5.8S-ITS2) was targeted for evaluation by semi-nested PCR. The first PCR reaction was performed using ITS1 (forward) and ITS4 (reverse) primers (Table 2). The total volume was $50 \mu$ l encompasses $45 \mu$ l of reaction mixture containing $1 \mathrm{mM} \mathrm{MgCl}_{2}, 1 \times$ of PCR buffer $10 x, 0.1 \mathrm{mM}$ each deoxynucleotide triphosphate (dNTP), 0.5 pmols/ $\mu$ l of each primer, $1 \mathrm{U}$ of Taq DNA polymerase, and $5 \mu$ of nucleic acid extract. In the second PCR step, the ITS1 (forward) and ITS2 (reverse) regions were amplified within the $3 \mu$ l of diluted $(1 / 100)$ product of the first PCR step. The product of first step was run into the second PCR to amplify ITS1 (forward) and ITS2 (reverse) regions in the same total volume (Table 2). PCR conditions for the first step were as follows; 10 min of initial denaturation at $94^{\circ} \mathrm{C}, 35$ cycles of $96^{\circ} \mathrm{C}$ for $45 \mathrm{~s}$, $58^{\circ} \mathrm{C}$ for $45 \mathrm{~s}$ and $72^{\circ} \mathrm{C}$ for $1 \mathrm{~min}$, and a $5 \mathrm{~min}$ final extension at $72^{\circ} \mathrm{C}$. Also, PCR conditions for the second step were as follows; 5 min of initial denaturation at $94^{\circ} \mathrm{C}, 32$ cycles of $94^{\circ} \mathrm{C}$ for $30 \mathrm{~s}, 60^{\circ} \mathrm{C}$ for $30 \mathrm{~s}$ and $72^{\circ} \mathrm{C}$ for $45 \mathrm{~s}$, and $5 \mathrm{~min}$ final extension at $72^{\circ} \mathrm{C}$ [15]. Both steps of the semi-nested PCR encompassed 10 to 20 samples included a positive control containing $0.5 \mathrm{ng}$ of purified DNA of one of the fungal isolates and at least two blanks with reagents only. Product quality and concentrations were estimated on the agarose gel, 
and analyzed by the Gel Doc XR system (Biorad, USA). Smart Ladder (Eurogentec, Seraing, Belgium) was used as the size and concentration marker.

\section{Sequencing}

To further confirmation of the results, PCR products were bidirectional chain terminated Sanger sequencing using referenced primers was performed. The obtained sequences were searched using the NBLAST algorithm (https://blast.ncbi.nlm.nih.gov/Blast.cgi) and the identity of each strain was assigned accordingly.

\section{Data Statistics}

Data were analyzed using SPSS software version 24. Briefly, descriptive data were presented as mean, standard deviation, percentages, and charts. The Chi-square and Fisher's exact tests were used to compare qualitative variables between the two groups. The Student t-test was used to compare quantitative variables between the two groups. Also, the Agreement between the two diagnostic methods was calculated by Kappa test, interpretation of Kappa was based on Viera et al. [23]. The p-value less than $0.05(P<0.05)$ was considered statistically significant.

\section{Results}

\section{Patients and samples}

One hundred ten FFPE samples were retrospectively collected from patients for two years (2018 to 2020$)$. Briefly, 50 patients were male (45.5\%) between 2 to 82 years old (mean age: 40.2 years old). The demographical data of the patients were truncated in the Table 1. Most patients with FRS had predisposing factors, which respectively including leukemia (20:64, 31.23\%), diabetes $(11: 64,17.11 \%)$, transplantation (4:64, 6.25\%), allergy (3:64, 4.7\%), polyp, autoimmune diseases, and drug addiction (1:64, 1.56\%). The crude mortality rate among 64 patients with FRS was $37.5 \%(24 / 64)$ but the mortality rate in mucormycosis was $53.7 \%(22 / 41)$.

\section{Histopathological Examinations}

Sixty-four samples were proven to positive for FRS. In 64\% (41 of 64) of them, ribbon-like non-septate or minimally septate hyaline mycelium were seen indicating mucormycosis (Figs. 1-3). Moreover, pathology evidence indicated that $31 \%$ (20 of 64) of FRS cases were chronic FRS, 3.12\% (2 of 64) were acute, and $1.56 \%$ (1 of 64 ) was acute/chronic FRS (Table 1). Forty-six non-FRS samples were included as controls.

\section{Molecular assay}

As shown in Table 3, 56 out of the 64 (87.5\%) histological proven specimens were positive for PCR (as shown in Fig. 4), and 8 samples (12.5\%) were negative. Out of 46 negative samples by histopathological methods, 41 samples (89.1\%) remained negative for PCR, while 5 (10.9) were positive. Moreover, 100\% (23/23) of chronic, acute, and acute/chronic FRS cases and 80.5\% (33/41) of mucormycosis cases were positive via semi-nested PCR method. Sensitivity, specificity, positive predictive value and negative predictive values of semi-nested PCR were $87.5 \%, 89.1 \%, 92.7 \%$, and 85.2\%, respectively. Moreover, kappa factor between these two methods were 0.76 indicating substantial agreements between these two tests. From the 
56 samples that were sequenced, 35 PCR product were successfully identified. The thirty-five sequences generated in this study were deposited in the GenBank database (accession numbers from MZ333236 to MZ333270 with persistent accessible links form MZ333236 to MZ333270, respectively). Eventually, Aspergillus flavus (12/35), Rhizopus oryzae (10/35), Lichtheimia corymbifra (3/35), Candida albicans (3/35) Aspergillus oryzae (1/35), A. parasiticus (1/35), A. fumigatus (1/35) Saksenaea vasiformis (1/35), Rhizopus microsporus (1/35), Alternaria alternata (1/35), and Cryptococcus uzbekistaniensis (1/35) were identified by sequencing of the ITS region.

Table 3

Comparing the results of histopathology and PCR assay

\begin{tabular}{|lll|}
\hline Pathology report & PCR result & Number (\%) \\
\hline FRS $(\mathrm{n}=64)$ & Positive & $56(87.5)$ \\
\cline { 2 - 3 } & Negative & $8(12.5)$ \\
\hline non-FRS $(\mathrm{n}=46)$ & Positive & $5(10.9)$ \\
\cline { 2 - 3 } & Negative & $41(89.1)$ \\
\hline Sensitivity & $87.5 \%$ & \\
\hline Specificity & $89.2 \%$ & \\
\hline Positive predictive value & $91.8 \%$ & \\
\hline Negative predictive value & $83.6 \%$ & \\
\hline
\end{tabular}

\section{Discussion}

By scrutiny in-field studies, several factors found to be affected the consequence of PCR assay in FFPE tissue samples. These factors are including DNA extraction method, inclusion of proper housekeeping gene, PCR method (i.e., panfungal, specific, nested, semi-nested, multiplex, and Real-Time), target gene(s) primers, amplicon length, thickness of FFPE cut, storage time of specimen, and contamination during sample preparation [24-26].

Here, we reached a sensitivity of $87.5 \%$ and a specificity of $89.1 \%$ for semi-nested PCR assay targeting ITS15.8s-ITS2 (ITS1-2) region of 110 FFPE-FESS samples. Bialek et al. indicated a $60.6 \%$ sensitivity and $100 \%$ specificity for nested PCR targeting 100-kDa-like-protein gene in 33 FFPE specimens, which were histopathologically proven for histoplasmosis [27]. Similarly, Willinger et al. indicated the $87 \%$ sensitivity for PCR of the $28 \mathrm{~S}$ region [28]. This may result from short amplicon length (260 bp) and pertinent primer pairs (U1/U2) to amplification the $28 \mathrm{~S}$ region. In another similar study, Rickerts et al. reported acceptable sensitively for molecular diagnosis of invasive aspergillosis and mucormycosis [29]. In both studies [22, 29], the DNA extraction method, gene targets, primer pairs, and amplicon length were similar. Lau et al. reported $82 \%$ positive results for panfungal PCR assay [30]. They also showed a sensitivity of $97 \%$ and $68 \%$ for fresh and FFPE samples, respectively which was lower than the results of current study. Cabaret et al. indicated 62.5\% and 93.75 positive results of FFPE samples for conventional PCR and APCR, respectively [31]. These 
differences may result from the differences in amplicon length ( $>300 \mathrm{bp}$ for conventional PCR vs. $150 \mathrm{bp}$ for qPCR) and the type of PCR method. In a similar study, Hammond et al. reported $81.5 \%$ positive results by semi-nested PCR of 18S rDNA using ZM1/ZM2 and ZM1/ZM3 primer pairs targeting an amplicon < $200 \mathrm{bp}$ [32]. Salehi et al. reported a $64 \%$ sensitivity for identification of fungi from FFPE by qPCR assay [33]. DrogariApiranthitou et al. [34] reached 45\% positive PCR for Mucorales and 40\% positive for Aspergillus spp. They reported $79.3 \%$ and $100 \%$ sensitivity and specificity for semi-nested PCR, respectively. The higher sensitivity of their method in comparison to us might be due to the more thickness of their tissue cuts ( $10 \mu \mathrm{m} v \mathrm{~s} .5 \mu \mathrm{m})$. In another study, Ganesan et al. reported the site of infection might affect the sensitivity of PCR test and reported that sensitivity rate increased from $63-83 \%$ for angioinvasion sites [35]. While Jung et al. indicated a $41.3 \%$ positive results for panfungal PCR, due to long amplicon length and may be inappropriate DNA extraction kit [36]. In our study we found a concordance rate of $76 \%$ for semi-nested PCR of the ITS region and histopathology assays which is similar to previous reports [30]. While others reported higher [33] or lower $[37,38]$ concordance rate between these two methods.

Due to the low amount of tissue in FFPE samples, the extracted DNA would be low. Hence, selection of proper extraction method is a key step in achieving a reliable amplification. Here, we used QIAamp DNA FFPE Tissue Kit (QIAGEN), as successfully used before [17, 28, 34, 37, 39-43]. In a comparative study between different commercial extraction kits, Muñoz-Cadavid et al. reported TaKaRa and QIAamp extraction kits yielded the best results for extraction of high quality DNA from the FFPE sample [44].

Similar to some previous studies [22, 32-34, 41,44], we used human $\beta$-globin gene as internal control and the primers successfully amplified the expected region in all samples. While others used different genes such as IRBP [38], GAPDH [27], and ZP3 [45] as controls.

In this study we used a panfungal semi-nested PCR for amplification of the ITS1-5.8s-ITS2 followed by ITS1 regions to detect fungal element in FFPE tissue samples which is concordant with a previous report [24]. Others amplified different targets such as 28S rDNA [43], ITS2 [35], 18S rDNA [34, 37] and mitochondrial tRNA [34] for detection of fungal DNA in FFPE samples. Although, Cabaret et al. suggest targeting mitochondrial DNA is superior to ITS [31], they obtained lower positive rate by conventional PCR $(10 / 16$, $62.5 \%)$ in comparison to ours (56/64, 87.5\%). In an another study, Jillwin et al. [37] targeted five different gene regions including universal ITS (ITS1-5.8s-ITS2), ITS1, ITS2, 18S rDNA, and D1/D2 of 28S rDNA and reported that ITS1 amplification leads to $61.9 \%$ positive results by PCR method.

The false-negative/positive consequences may result from the following reasons: First, false-positive histopathological results artifacts during staining. Second, the presence of conserved genes in multiple copies (rDNA) is a disadvantage in clinical specimens collected from nonsterile body sites, because nonpathogenic commensal fungi, environmental spores, or colonizing fungi can also cause considerable nonspecific amplification in samples consisting mainly of human cells with only a few fungal cells. Third, proteins-DNA cross-linking formation and fragmentation of DNA during the fixation process leads to a lack of intact DNA needed for amplification. More specifically, it is difficult to amplify the target gene when DNA is highly fragmented or cross-linked and the amplicon size is large. Fourth, amplification of a housekeeping gene (human $\beta$-globin) in tissue does not necessarily mean the presence of a sufficient amount of amplifiable fungal DNA.

Page $12 / 20$ 
It is recommended that a shorter amplicon length gives higher sensitivity and specificity rates for PCR results [26]. Also, it recommended that semi-nested PCR assays performed in a single tube, which showed less prone to contamination when compared with assays that carried out in two stages and in separate tubes. As Aspergillus species and Mucorales are most frequent causative agents of FRS, it can be a good idea to use species-specific primers and multiplex PCR to differentiate them as soon as possible in a single reaction.

\section{Conclusion}

In this study amplification of ITS1-5.8S-ITS2 by semi-nested PCR in FFPE samples of IFI yielded a considerable result with sensitivity and specificity of $87.5 \%$ and $89.1 \%$, respectively. Considering low amounts of samples obtained by endoscopy-guided biopsy and rapid clinical progress of rhinocerebral mucormycosis, establishment a rapid, accurate and reliable molecular method for direct detection of FRS in FFPE samples might improve the outcomes.

\section{List Of Abbreviations}

FRS

Fungal rhinosinusitis

PCR

polymerase chain reaction

FFPE

formalin-fixed paraffin-embedded

FESS

functional endoscopic sinus surgery

ITS

internal transcribed spacer

AFRS

allergic fungal rhinosinusitis

$\mathrm{KOH}$

potassium hydroxide

GMS

Gomori methenamine silver

$H \& E$

hematoxylin and eosin

SDA

Sabouraud dextrose agar

SC

Sabouraud-chloramphenicol

SCC

Sabouraud-chloramphenicol- Cycloheximide

qPCR

Quantitative Real-time PCR 
CT

computed tomography

PAS

Periodic Acid Schiff

\section{Declarations}

Ethics approval and consent to participate: All methods were performed in accordance with the relevant guidelines and regulations. This study were supervised and monitored by the Ethics Committee of Shiraz University of Medical Sciences (permission code: IR.SUMS.REC.1393.S7348). Informed consent were taken from all participants and parents/legally authorized representative of all minor (age less than 16 years) and deceased participants involved in the study.

Consent for publication: Not applicable.

Availability of data and materials: The thirty-five sequences generated in this study were deposited in the GenBank database (accession numbers from MZ333236 to MZ333270 with persistent accessible links form MZ333236 to MZ333270, respectively). All data used to support the findings of this study are available from corresponding author upon request.

Competing interests: The authors declare that they have no competing interests.

Funding: This project received financial support from the Vice President of Research, Shiraz University of Medical Sciences (Grant \& Thesis No. 937348).

Authors' contributions: M. JA, M.K, K.P, H.M and K.Z designed the study. M.JA, G.S, B.K, and M.S collected and prepared study samples. M.K, S.A, K.A, F.S, and K.Z performed molecular assays and data analysis. M. JA, G.S, performed histopathological tests. M.K, H.M, H.B, K.P, and K.Z drafted the manuscript, acquired the data; analysed and interpreted the data. All authors read, revised and approved the final manuscript.

Acknowledgements: The authors are grateful to Khalili Educational and Research Hospital, Shiraz-Iran and Vice President of Research, Shiraz University of Medical Sciences for great support of this project.

\section{References}

1. Kwah JH, Peters AT: Nasal polyps and rhinosinusitis. In: Allergy \& Asthma Proceedings: $2019 ; 2019$.

2. DeConde AS, Soler ZM: Chronic hinosinusitis: epidemiology and burden of disease. American journal of rhinology \& allergy 2016, 30(2):134-139.

3. Bhattacharyya N, Orlandi RR, Grebner J, Martinson M: Cost burden of chronic rhinosinusitis: a claimsbased study. Otolaryngology-Head and Neck Surgery 2011, 144(3):440-445.

4. Scangas GA, Wu AW, Ting JY, Metson R, Walgama E, Shrime MG, Higgins TS: Cost utility analysis of dupilumab versus endoscopic sinus surgery for chronic rhinosinusitis with nasal polyps. The Laryngoscope 2020. 
5. Singh V: Fungal rhinosinusitis: unravelling the disease spectrum. Journal of maxillofacial and oral surgery 2019, 18(2):164-179.

6. Suresh S, Arumugam D, Zacharias G, Palaninathan S, Vishwanathan R, Venkatraman V: Prevalence and clinical profile of fungal rhinosinusitis. Allergy \& Rhinology 2016, 7(2):ar. 2016.2017. 0156.

7. Deutsch PG, Whittaker J, Prasad S: Invasive and Non-Invasive Fungal Rhinosinusitis-A Review and Update of the Evidence. Medicina 2019, 55(7):319.

8. Chakrabarti A: Fungal rhinosinusitis. In: Clinical Practice of Medical Mycology in Asia. edn.: Springer; 2020: 165-176.

9. Montone KT: Pathology of fungal rhinosinusitis: a review. Head and neck pathology 2016, 10(1):40-46.

10. Patrascu E, Manea C, Sarafoleanu C: Difficulties in the diagnosis of fungal rhinosinusitis-literature review. Romanian Journal of Rhinology 2016, 6(21):11-17.

11. Singh AK, Gupta P, Verma N, Khare V, Ahamad A, Verma V, Agarwal S: Fungal rhinosinusitis: microbiological and histopathological perspective. Journal of clinical and diagnostic research: JCDR 2017, 11(7):DC10.

12. Tyler MA, Padro Dietz CJ, Russell CB, Citardi MJ, Assassi S, Ying J, Luong AU: Distinguishing molecular features of allergic fungal rhinosinusitis. Otolaryngology-Head and Neck Surgery 2018, 159(1):185193.

13. Mohammadi A, Hashemi SM, Abtahi SH, Lajevardi SM, Kianipour S, Mohammadi R: An investigation on non-invasive fungal sinusitis; Molecular identification of etiologic agents. Journal of research in medical sciences: the official journal of Isfahan University of Medical Sciences 2017, 22.

14. Badiee $\mathrm{P}$, Moghadami M, Rozbehani $\mathrm{H}$ : Comparing immunological and molecular tests with conventional methods in diagnosis of acute invasive fungal minosinusitis. The Journal of Infection in Developing Countries 2016, 10(01):90-95.

15. Badiee P, Gandomi B, Sabz G, Khodami B, Choopanizadeh M, Jafarian H: Evaluation of nested PCR in diagnosis of fungal thinosinusitis. Iranian journal of microbiology 2015, 7(1):62.

16. Saravanan K, Panda NK, Chakrabarti A, Das A, Bapuraj RJ: Allergic fungal rhinosinusitis: an attempt to resolve the diagnostic dilemma. Archives of Otolaryngology-Head \& Neck Surgery 2006, 132(2):173178.

17. Frickmann H, Loderstaedt U, Racz P, Tenner-Racz K, Eggert P, Haeupler A, Bialek R, Hagen RM: Detection of tropical fungi in formalin-fixed, paraffin-embedded tissue: still an indication for microscopy in times of sequence-based diagnosis? BioMed research international 2015, 2015.

18. Stewart CJ, Fatemizadeh R, Parsons P, Lamb CA, Shady DA, Petrosino JF, Hair AB: Using formalin fixed paraffin embedded tissue to characterize the preterm gut microbiota in necrotising enterocolitis and spontaneous isolated perforation using marginal and diseased tissue. BMC microbiology 2019, 19(1):1-10.

19. Challa S, Pamidi U, Uppin SG, Uppin MS, Vemu L: Diagnostic accuracy of morphologic identification of filamentous fungi in paraffin embedded tissue sections: correlation of histological and culture diagnosis. Indian Journal of Pathology and Microbiology 2014, 57(4):583. 
20. Bialek R, Ibricevic A, Aepinus C, Najvar LK, Fothergill AW, Knobloch J, Graybill JR: Detection of Paracoccidioides brasiliensis in tissue samples by a nested PCR assay. Journal of clinical microbiology 2000, 38(8):2940-2942.

21. Chan MK, Lau K, Tsui Y, Wong FW, Huang DP: Human papillomavirus infection in Hong Kong Chinese women with normal and abnormal cervix-detection by polymerase chain reaction method on cervical scrapes. Gynecologic oncology 1996, 60(2):217-223.

22. Bialek R, Konrad F, Kern J, Aepinus C, Cecenas L, Gonzalez G, Just-Nübling G, Willinger B, Presterl E, Lass-Flörl C: PCR based identification and discrimination of agents of mucormycosis and aspergillosis in paraffin wax embedded tissue. Journal of Clinical Pathology 2005, 58(11):1180-1184.

23. Viera AJ, Garrett JM: Understanding interobserver agreement: the kappa statistic. Fam med 2005, $37(5): 360-363$.

24. Sarnecka AK, Nawrat D, Piwowar M, Ligęza J, Swadźba J, Wójcik P: DNA extraction from FFPE tissue samples-a comparison of three procedures. Contemporary Oncology 2019, 23(1):52.

25. Fujii S, Yoshino T, Yamazaki K, Muro K, Yamaguchi K, Nishina T, Yuki S, Shinozaki E, Shitara K, Bando H: Histopathological factors affecting the extraction of high quality genomic DNA from tissue sections for next-generation sequencing. Biomedical reports 2019, 11(4):171-180.

26. Rickerts $\mathrm{V}$ : Identification of fungal pathogens in formalin-fixed, paraffin-embedded tissue samples by molecular methods. Fungal biology 2016, 120(2):279-287.

27. Bialek R, Feucht A, Aepinus C, Just-Nübling G, Robertson VJ, Knobloch J, Hohle R: Evaluation of two nested PCR assays for detection of Histoplasma capsulatum DNA in human tissue. Journal of Clinical Microbiology 2002, 40(5):1644-1647.

28. Willinger B, Obradovic A, Selitsch B, Beck-Mannagetta J, Buzina W, Braun H, Apfalter P, Hirschl AM, Makristathis $A$, Rotter $M$ : Detection and identification of fungi from fungus balls of the maxillary sinus by molecular techniques. Journal of clinical microbiology 2003, 41(2):581-585.

29. Rickerts V, Just-Nübling G, Konrad F, Kern J, Lambrecht E, Böhme A, Jacobi V, Bialek R: Diagnosis of invasive aspergillosis and mucormycosis in immunocompromised patients by seminested PCR assay of tissue samples. European Journal of Clinical Microbiology and Infectious Diseases 2006, 25(1):8-13.

30. Lau A, Chen S, Sorrell T, Carter D, Malik R, Martin P, Halliday C: Development and clinical application of a panfungal PCR assay to detect and identify fungal DNA in tissue specimens. Journal of clinical microbiology 2007, 45(2):380-385.

31. Cabaret O, Toussain G, Abermil N, Alsamad IA, Botterel F, Costa J-M, Papon J-F, Bretagne S: Degradation of fungal DNA in formalin-fixed paraffin-embedded sinus fungal balls hampers reliable sequence-based identification of fungi. Medical mycology 2011, 49(3):329-332.

32. Hammond SP, Bialek R, Milner DA, Petschnigg EM, Baden LR, Marty FM: Molecular methods to improve diagnosis and identification of mucormycosis. Journal of Clinical Microbiology 2011, 49(6):2151-2153.

33. Salehi E, Hedayati MT, Zoll J, Rafati H, Ghasemi M, Doroudinia A, Abastabar M, Tolooe A, Snelders E, Van Der Lee HA: Discrimination of aspergillosis, mucormycosis, fusariosis, and scedosporiosis in formalin-fixed paraffin-embedded tissue specimens by use of multiple real-time quantitative PCR assays. Journal of clinical microbiology 2016, 54(11):2798-2803. 
34. Drogari-Apiranthitou M, Panayiotides I, Galani I, Konstantoudakis S, Arvanitidis G, Spathis A, Gouloumi A-R, Tsakiraki Z, Tsiodras S, Petrikkos G: Diagnostic value of a semi-nested PCR for the diagnosis of mucormycosis and aspergillosis from paraffin-embedded tissue: A single center experience. PathologyResearch and Practice 2016, 212(5):393-397.

35. Ganesan A, Wells J, Shaikh F, Peterson P, Bradley W, Carson ML, Petfield JL, Klassen-Fischer M, Akers KS, Downing $\mathrm{K}$ : Molecular detection of filamentous fungi in formalin-fixed paraffin-embedded specimens in invasive fungal wound infections is feasible with high specificity. Journal of clinical microbiology 2019, 58(1).

36. Jung IY, Lee Y-J, Shim HS, Lee WJ, Kim JH, Seong H, Kim JH, Ahn JY, Jeong SJ, Ku NS: Panfungal PCR assays using fresh frozen paraffin embedded tissue specimens for fungal species identification and the detection of azole-resistance mutations in the A. fumigatus cyp51A gene at a South Korean hospital. 2019.

37. Jillwin J, Rudramurthy SM, Singh S, Bal A, Das A, Radotra B, Prakash H, Dhaliwal M, Kaur H, Ghosh AK: Molecular identification of pathogenic fungi in formalin-fixed and paraffin-embedded tissues. Journal of Medical Microbiology 2020:jmm001282.

38. Meason-Smith C, Edwards EE, Older CE, Branco M, Bryan LK, Lawhon SD, Suchodolski JS, Gomez G, Mansell J, Hoffmann AR: Panfungal polymerase chain reaction for identification of fungal pathogens in formalin-fixed animal tissues. Veterinary pathology 2017, 54(4):640-648.

39. Larkin PM, Lawson KL, Contreras DA, Le CQ, Trejo M, Realegeno S, Hilt EE, Chandrasekaran S, Garner OB, Fishbein GA: Amplicon-Based Next-Generation Sequencing for Detection of Fungi in Formalin-Fixed, Paraffin-Embedded Tissues: Correlation with Histopathology and Clinical Applications. The Journal of Molecular Diagnostics 2020, 22(10):1287-1293.

40. Flury BB, Weisser M, Prince SS, Bubendorf L, Battegay M, Frei R, Goldenberger D: Performances of two different panfungal PCRs to detect mould DNA in formalin-fixed paraffin-embedded tissue: what are the limiting factors? BMC infectious diseases 2014, 14(1):1-9.

41. Sadamoto S, Shinozaki M, Nagi M, Nihonyanagi Y, Ejima K, Mitsuda A, Wakayama M, Tochigi N, Murakami Y, Hishima T: Histopathological study on the prevalence of trichosporonosis in formalin-fixed and paraffin-embedded tissue autopsy sections by in situ hybridization with peptide nucleic acid probe. Medical mycology 2020, 58(4):460-468.

42. Zeng H, Li X, Chen X, Zhang J, Sun J, Xie Z, Xi L: Identification of Penicillium marneffei in paraffinembedded tissue using nested PCR. Mycopathologia 2009, 168(1):31-35.

43. Gholinejad-Ghadi N, Shokohi T, Seifi Z, Aghili SR, Roilides E, Nikkhah M, Pormosa R, Karami H, Larjani LV, Ghasemi M: Identification of Mucorales in patients with proven invasive mucormycosis by polymerase chain reaction in tissue samples. Mycoses 2018, 61(12):909-915.

44. Muñoz-Cadavid C, Rudd S, Zaki S, Patel M, Moser S, Brandt M, Gomez B: Improving molecular detection of fungal DNA in formalin-fixed paraffin-embedded tissues: comparison of five tissue DNA extraction methods using panfungal PCR. Journal of clinical microbiology 2010, 48(6):2147-2153.

45. Chaturantabut S, Kitkumtorn N, Mutirangura A, Praditphol N, Chindamporn A, Thorner P, Keelawat S: Identification of pathogens causing invasive fungal rhinosinusitis in surgical biopsies using polymerase 
chain reaction. The Journal of Laryngology \& Otology 2020, 134(7):632-635.

\section{Figures}

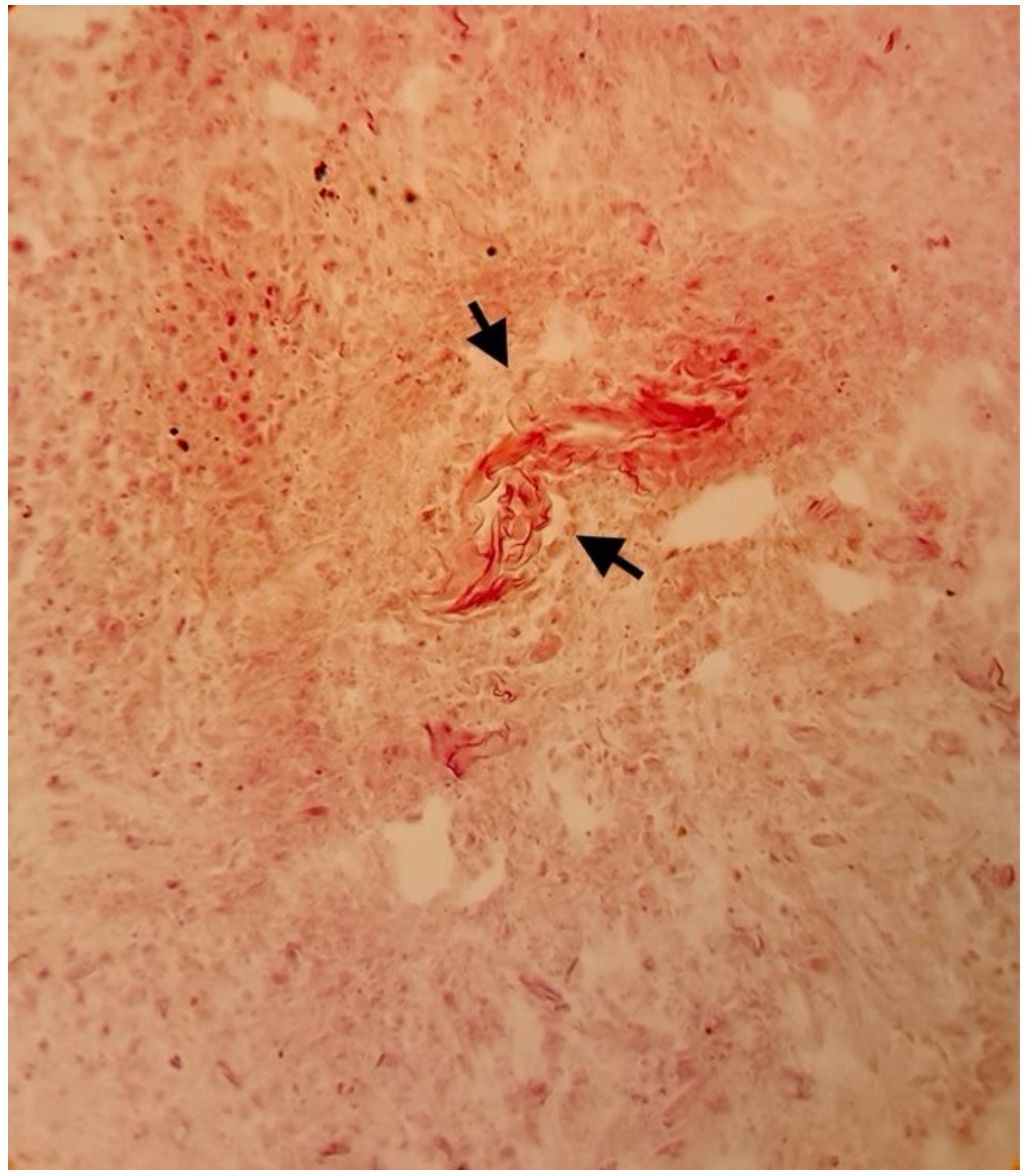

Figure 1

Mucor hyphae in a necrotic background of sinusal tissue, H\&E stain ( $x 400)$ 


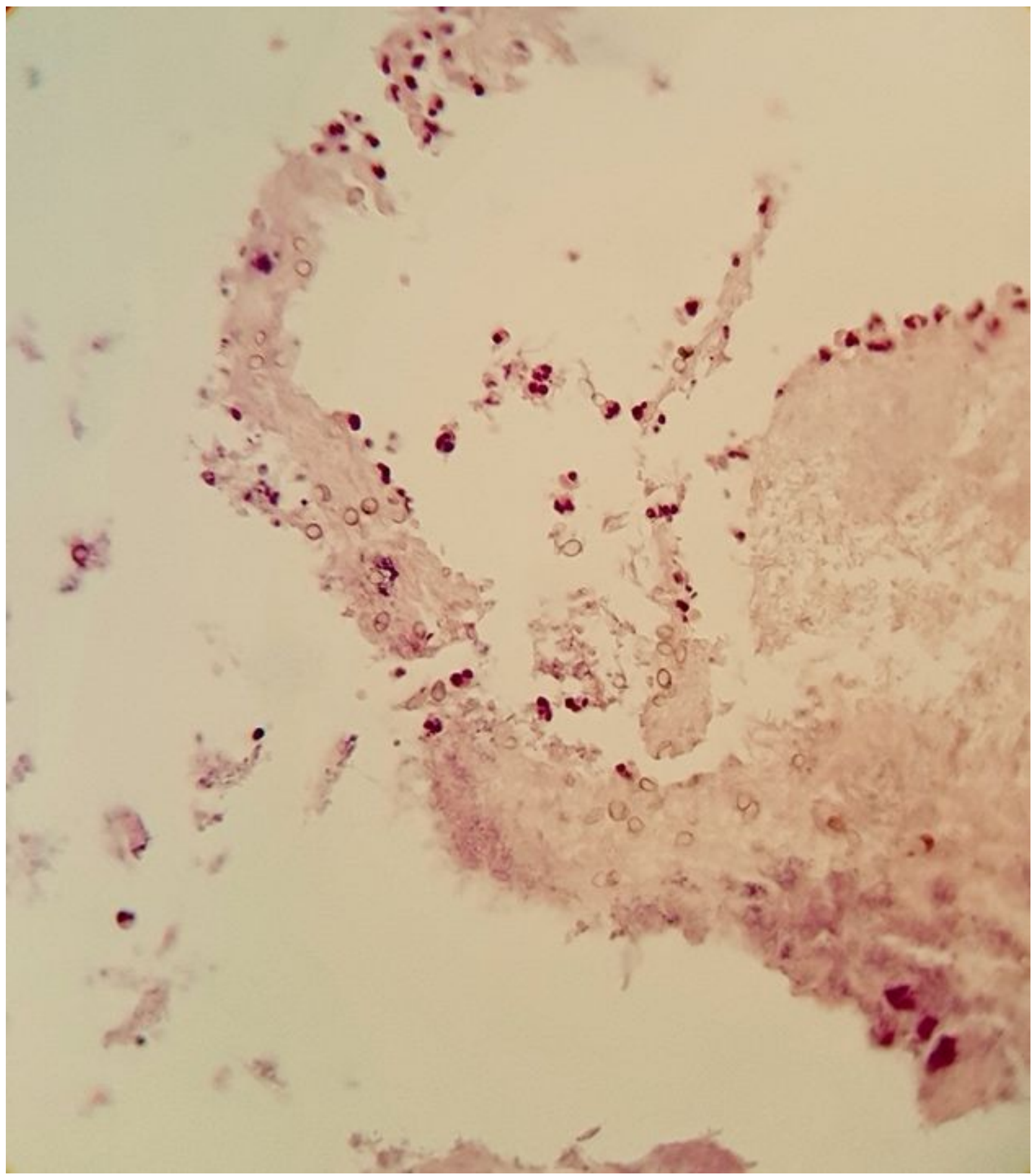

Figure 2

Fungal spores in the sinusal tissue of chronic sinusitis, H\&E stain (X400) 


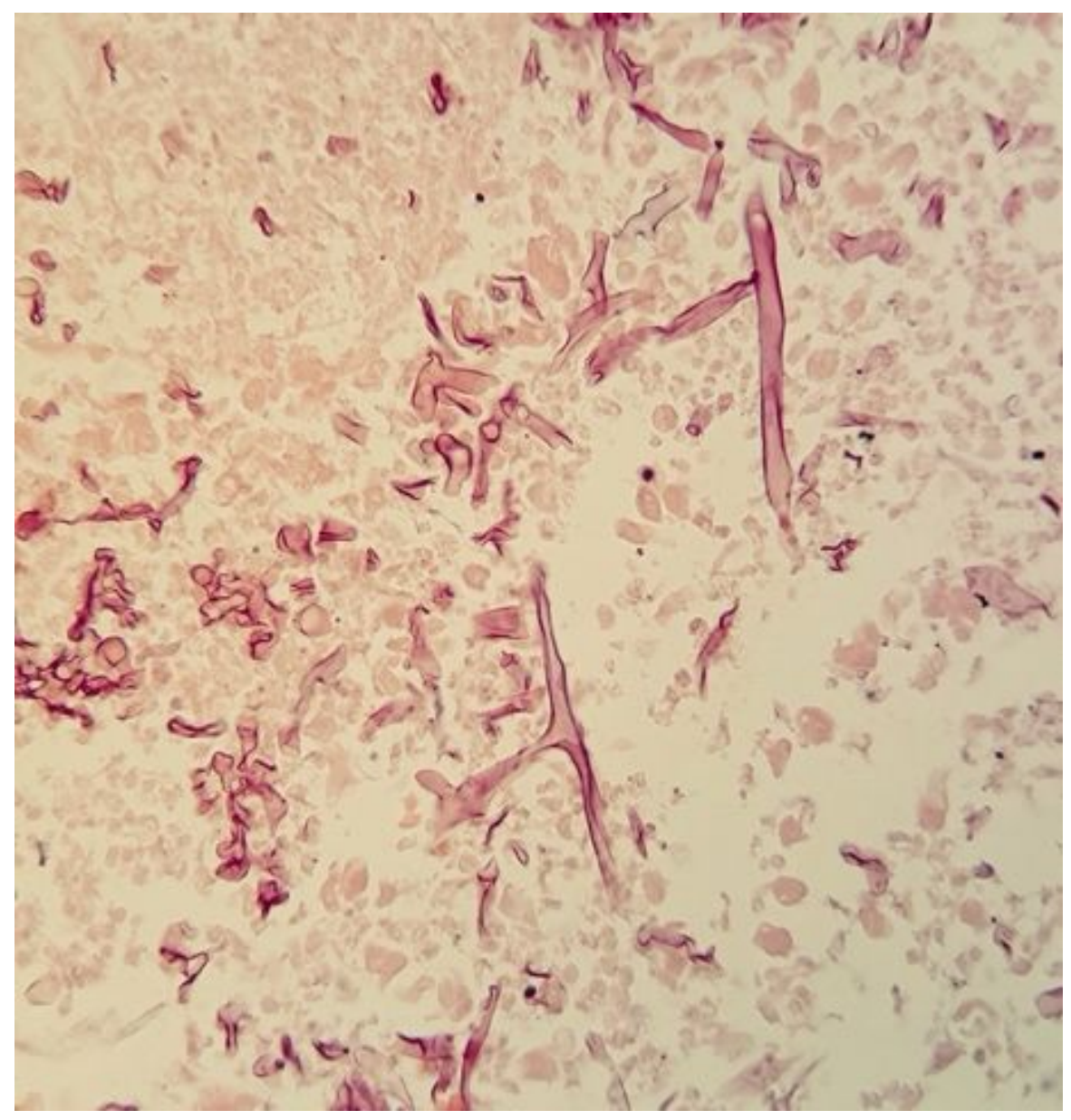

Figure 3

non-septate hyphae in the sinusal tissue, H\&E stain ( $x 400)$

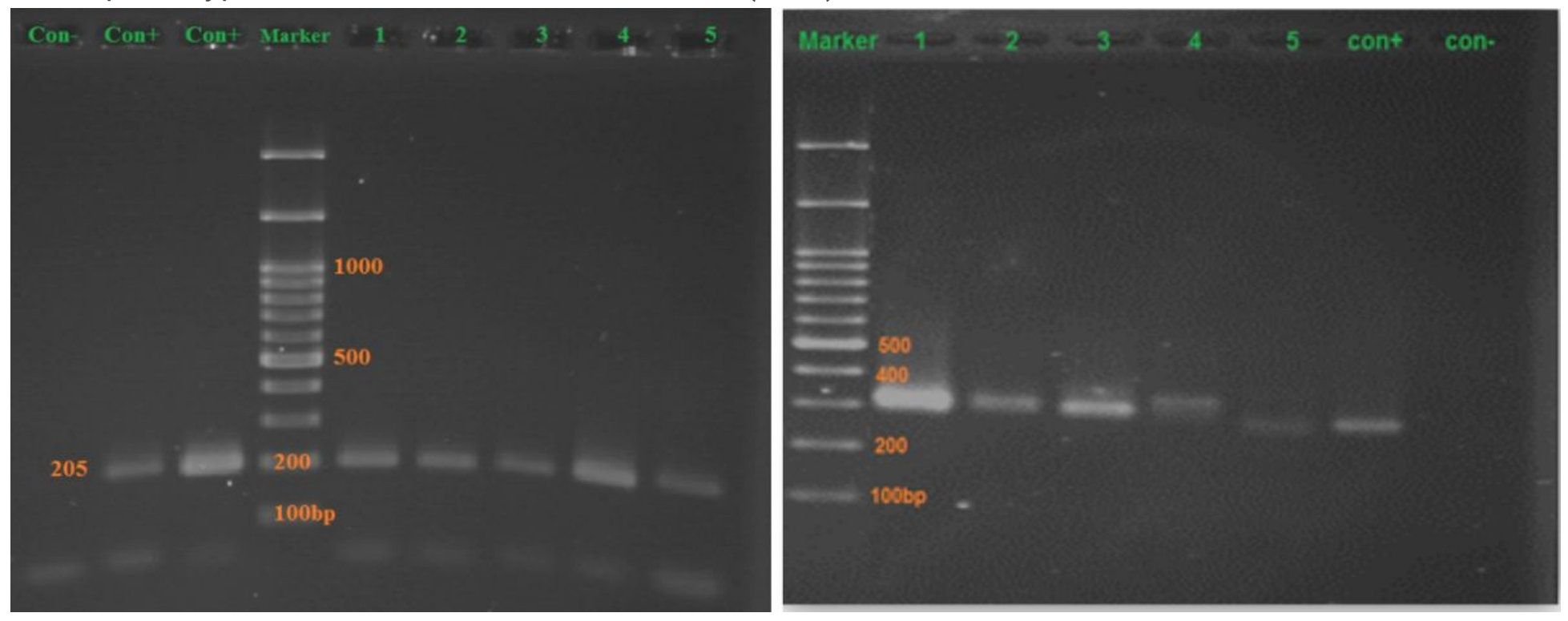

\section{Figure 4}

Gel electrophoresis primary PCR via $\beta$-globin (left) and semi-nested PCR for ITS region (wright) 